\title{
Initial geological considerations before installing ground source heat pump
}

\section{systems}

\author{
Jon Busby ${ }^{1 a}$, Melinda Lewis ${ }^{2}$, Helen Reeves ${ }^{1}$, Russell Lawley ${ }^{1}$ \\ ${ }^{1}$ British Geological Survey, Keyworth, Nottingham, NG12 5GG \\ ${ }^{2}$ British Geological Survey, Crowmarsh Gifford, Wallingford, OX10 8BB
}

ae-mail: jpbu@bgs.ac.uk

\begin{abstract}
The performance of an open or closed loop ground source heat pump system depends on local geological conditions. It is important these are determined as accurately as possible when designing a system in order to maximise efficiency and minimise installation costs. Factors that need to be considered are surface temperature, sub-surface temperatures down to $100-200 \mathrm{~m}$, thermal conductivities and diffusivities of the soil and rock layers, groundwater levels and flows and aquifer properties. In addition rock strength is a critical factor in determining the excavation or drilling method required at a site and the associated costs. The key to determining all of these factors is an accurate conceptual site scale model of the ground conditions (soils, geology, thermogeology, engineering geology and hydrogeology). The British Geological Survey has used the modern digital geological mapping of the UK as a base onto which appropriate attributes can be assigned. As a result it is possible to generate regional maps of surface and sub-surface temperatures, rock strength and depth to water. This information can be used by designers, planners and installers of ground source heat pump systems. The use of appropriate geological factors will assist in creating a system that meets the heating or cooling load of the building without unnecessary over engineering.
\end{abstract}




\section{Introduction}

This paper is one of a thematic set entitled Hydrogeology and Heat Engineering. The use of groundwater, abstracted via open loop systems, is increasingly being considered as a means to provide heating and cooling for buildings, particularly in London. In order to avoid unnecessary repetition between papers in the set, the background to the science of thermogeology and the exploitation of ground source heat is described by Banks (2009) and the UK regulatory environment by Fry (2009) in which paper is also to be found an outline of the hydrogeology of the London Basin where many of the UK's largest open loop ground source heating and cooling schemes are located.

The uptake of Ground Source Heat Pump (GSHP) technology in the UK has been slow and has lagged behind that of much of continental Europe (EEBPP, 2000; Sanner et al., 2003; Curtis et al., 2005). However, increasing fossil fuel prices and a greater awareness of environmental issues are creating an ever greater demand for both heating and cooling GSHP systems. Recent figures released by the UK Department for Business Enterprise and Regulatory Reform (DBERR, 2007) estimate that the number of installations could increase to 10,000 units installed by $2010,35,000$ by 2015 and 55,000 by 2020 .

GSHPs can be installed at virtually any location (Rybach \& Sanner, 2000), but the type of system, open or closed loop; the choice of ground collector loop, horizontal or vertical and the size of the loop all depend on local geological conditions (Sanner et al., 2003; HEEBPP, 2003; Ondreka et al., 2007). To date most installations in the UK have been for heating (with the exception of recent demand for cooling in London). It is essential that the design of the wells for an open loop system or the collector loop for a closed loop system are optimised to meet the heating or cooling demand of the building. Since the drilling of boreholes or emplacement of the ground collector loop represents a significant proportion of the installation costs it is important that these are not unnecessarily over engineered. The UK has 
a complex geology and this has been cited as one of the factors that has led to a slow uptake of GSHPs in the UK (Curtis, 2001). Publications are available that list information sources for the geological conditions for some countries, e.g. Rafferty (2001) for the USA. This paper reviews the geological factors that are pertinent to the choice and design of the ground component of a GSHP system and presents data relevant to the UK.

\section{Factors impacting on the ground component of a GSHP system}

Figure 1 is a sketch of the main factors that impact on the design of the ground component of a GSHP system. It shows a hypothetical situation where the bedrock geology is dipping and is exposed on the flanks of a hill. At the top of the hill the bedrock is overlain by superficial deposits. The location of ground collector loops for a horizontal closed loop system and a vertical closed loop system are indicated by HL and VL respectively. The temperature of the ground in the vicinity of the loops determines the temperature gradient between the ground and the loops that drives the heat transfer. Hence, ground temperature impacts directly on the heating or cooling efficiency of the system. The rock strength, thickness of superficial deposits and depth of weathered bedrock all affect the ground conditions and hence the trenching or drilling methods used and their associated costs. When drilling to depths of 100 $\mathrm{m}$, several formations with different physical properties might be encountered. Each of the formations around the ground collector loop may have different thermal properties and these will affect the heat exchange performance. Groundwater has major impacts for both open and closed loop systems. Thermal properties are diminished when rocks become unsaturated and hence groundwater levels impact on heat exchange performance. Groundwater flow will transport heat and affects the heating and cooling performance for both open and closed loop systems. Downward groundwater flow is detrimental for heating applications as it generally transports cooler water to depth, whilst upward flow has the opposite effect. Mine workings can present a hazard when shallow as they may unexpectedly be encountered when drilling. 
However, at depth, mine workings can be exploited as a possible source for open loop or standing water column systems (Banks et al., 2009a).

\section{Thermal properties}

The rate at which heat can be transferred to the heat exchanger from the ground, or to the ground, is determined mainly by the thermal properties of the earth, i.e. thermal conductivity and thermal diffusivity. Thermal conductivity is the capacity of a material to conduct or transmit heat, whilst thermal diffusivity describes the rate at which heat is conducted through a medium. It is related to thermal conductivity, heat capacity and density via the equation:

$$
\alpha=\frac{\lambda}{C_{p} \rho}
$$

Where $\alpha=$ thermal diffusivity $\left(\mathrm{m}^{2} \mathrm{~s}^{-1}\right), \lambda=$ thermal conductivity $\left(\mathrm{W} \mathrm{m} \mathrm{m}^{-1} \mathrm{~K}^{-1}\right), \mathrm{C}_{\mathrm{p}}=$ specific heat capacity $\left(\mathrm{J} \mathrm{kg}^{-1} \mathrm{~K}^{-1}\right)$ and $\rho=$ density $\left(\mathrm{kg} \mathrm{m}^{-3}\right)$.

General tables of thermal conductivities are available (e.g. Robertson, 1988) and typical values for UK rocks have been published by Rollin (1987) and Bloomer (1981). Thermal conductivity varies by a factor of more than two for the range of common rocks encountered at the surface. Superficial deposits and soils are complex aggregates of mineral and organic particles and so exhibit a wide range of thermal characteristics. The level of water saturation has a significant impact on the thermal conductivity of superficial deposits; typical values for which are shown in Table 1. For sedimentary rocks, the primary controls on thermal conductivity are the lithology, porosity, and extent of saturation. Mudstones and clays have thermal conductivities in the range $1.2-2.3 \mathrm{~W} \mathrm{~m}^{-1} \mathrm{~K}^{-1}$. For low porosity $(<30 \%)$ shale, sandstone and siltstone the mean thermal conductivity is in the range $2.2-2.6 \mathrm{~W} \mathrm{~m}^{-1} \mathrm{~K}^{-1}$. Water has a thermal conductivity of $0.6 \mathrm{~W} \mathrm{~m}^{-1} \mathrm{~K}^{-1}$ and air a thermal conductivity of 0.0252 $\mathrm{W} \mathrm{m} \mathrm{m}^{-1} \mathrm{~K}^{-1}$. A saturated quartz sandstone with $5 \%$ porosity might have a thermal conductivity of about $6.5 \mathrm{~W} \mathrm{~m}^{-1} \mathrm{~K}^{-1}$ but this would decrease to about $2.5 \mathrm{~W} \mathrm{~m}^{-1} \mathrm{~K}^{-1}$ if the rock had a 
porosity of $30 \%$. Porosity is also the main influence on thermal conductivity of volcanic rocks. Low porosity tuffs, lavas and basalts may have values above $2 \mathrm{~W} \mathrm{~m}^{-1} \mathrm{~K}^{-1}$, but at $10 \%$ porosity with water saturation this might reduce to about $1.5 \mathrm{~W} \mathrm{~m}^{-1} \mathrm{~K}^{-1}$. For intrusive igneous rocks, which generally have a much lower porosity, the thermal conductivity variation is less. Intrusive rocks with low feldspar content $(<60 \%)$, including granite, granodiorite, diorite, gabbro and many dykes, have a mean thermal conductivity of about $3.0 \mathrm{~W} \mathrm{~m}^{-1} \mathrm{~K}^{-1}$. For metamorphic rocks, porosity is often very low and thermal conductivity can be related to quartz content. The thermal conductivity of quartzites is high, typically above $5.5 \mathrm{~W} \mathrm{~m}^{-1} \mathrm{~K}^{-1}$. For schists, hornfels, quartz mica schists, serpentinites and marbles the mean thermal conductivity is about $2.9 \mathrm{~W} \mathrm{~m}^{-1} \mathrm{~K}^{-1}$.

Typical rock thermal diffusivities range from about $0.75 \times 10^{-6} \mathrm{~m}^{2} \mathrm{~s}^{-1}$ for clays to about $2.0 \mathrm{x}$ $10^{-6} \mathrm{~m}^{2} \mathrm{~s}^{-1}$ for high conductivity rocks such as anhydrite and pure quartzites. Most rocks have thermal diffusivities in the range 0.9-1.2 $10^{-6} \mathrm{~m}^{2} \mathrm{~s}^{-1}$. Generally, thermal conductivity and specific heat are increased for saturated rocks and diffusivity is also enhanced. Table 2 gives representative values of thermal diffusivity and conductivity for various rock types.

\section{Temperature}

The ground surface of the earth is heated by solar radiation. It has been estimated that the annual mean net incoming radiation is typically within the range $40-80 \mathrm{~W} \mathrm{~m}^{-2}$ for temperate Europe (Linacre and Geerts, 1997). Soil temperatures vary both with daily and seasonal cycles, the former dying out within a few $10 \mathrm{~s}$ of $\mathrm{cm}$ and the latter at greater depths, but at depths of about $15 \mathrm{~m}$ the temperature is approximately constant and equal to the mean annual air temperature (Rybach \& Sanner, 2000). The annual function of air temperature is transmitted down through the earth at a rate dependent on thermal diffusivity. Consequently the temperature function in the near sub-surface has a progressive phase shift (e.g. Keery et $a l ., 2007)$. This means that at times of minimum air temperature ground temperatures are 
generally slightly higher and at times of maximum air temperatures ground temperatures are lower (see Figure 2). This effect is well known to anyone with a cellar and is beneficial for GSHP heating and cooling.

The UK Meteorological Office collects and archives climate temperature data. Monthly and annual long-term average datasets have been generated for the periods 1961-1990 and 19712000 (Perry \& Hollis, 2005a). Mean annual air temperatures at sea level in mainland UK varies from north to south from about $8-12{ }^{\circ} \mathrm{C}$ and the January - July mean air temperature swing for much of the UK is less than $15{ }^{\circ} \mathrm{C}$ (Perry \& Hollis, 2005b). Mean annual air temperatures show a general decrease eastwards and northwards from highest values in the SW of England. Since the contribution to surface temperature from terrestrial heat flow is very small, the mean annual ground surface temperature should be close to the mean annual air temperature, although it often shows a variation of $\pm 1{ }^{\circ} \mathrm{C}$ (Rollin, 2002). Mean annual air temperatures are mainly affected by position and elevation. The slope of the local terrain, aspect of the site, i.e. whether south or north facing and exposure of the site, i.e. sheltered or open also have an effect, but it is generally small.

Given a location and height, an estimate of the mean annual air temperature can be made. A simple seven point polynomial function has been fitted to the UKMO annual long-term average data to create a model of mean annual air temperature. A sample of UKMO stations for 1995 was tested using this model. Of 451 stations the root mean square error for the fit was $0.75{ }^{\circ} \mathrm{C}$ with maximum and minimum errors of $+3.0^{\circ} \mathrm{C}$ and $-4.1{ }^{\circ} \mathrm{C}$ respectively. Including distance from the sea as a further element in the polynomial gave no significant improvement in the model fit. Hence, a reasonable estimate of mean annual air temperature can be made for anywhere in Great Britain.

Below a depth of around $15 \mathrm{~m}$, temperatures are also affected by the small amount of heat that is conducted upwards from the interior of the earth. This component is the heat flow and 
a heat flow map for the UK is shown in Figure 3 (Lee et al., 1987; Downing \& Gray, 1986; Rollin, 1995; Barker et al., 2000). There is a fairly uniform background field of around 0.052 $\mathrm{W} \mathrm{m} \mathrm{m}^{-2}$. Areas of increased heat flow are associated with the radiogenic granites of the $\mathrm{SW}$ of England and the buried granites of northern England. Values are also above the regional background over the batholith in the Eastern Highlands of Scotland. As a result of the heat flow, temperatures increase with depth; the average UK geothermal gradient is $0.026{ }^{\circ} \mathrm{C} \mathrm{m}^{-1}$, but locally it can be in excess of $0.035^{\circ} \mathrm{C} \mathrm{m}^{-1}$.

It is possible to estimate temperatures at $100 \mathrm{~m}$ depth by applying Fourier's Law of heat conduction:

$$
\mathrm{q}=-\lambda \operatorname{grad} \mathrm{T}
$$

where $\mathrm{q}=$ heat flow $\left(\mathrm{W} \mathrm{m} \mathrm{m}^{-2}\right), \lambda=$ thermal conductivity $\left(\mathrm{W} \mathrm{m}^{-1} \mathrm{~K}^{-1}\right)$ and $\operatorname{grad} \mathrm{T}=$ temperature gradient $\left(\mathrm{K} \mathrm{m}^{-1}\right)$. Thermal conductivity has been taken as the thermal conductivity of the bedrock geology (i.e. the rock below the soil and superficial deposits layers). The calculated temperature gradient has been added to the estimate of the mean annual air temperature to generate the estimate of temperature at $100 \mathrm{~m}$ depth and is shown for Great Britain in Figure 4. The assumptions of consistent geology to $100 \mathrm{~m}$ depth and no contribution from groundwater flow are clearly simplistic, but should not result in serious errors for the upper $100 \mathrm{~m}$. These modelled values have been compared to 90 equilibrium borehole temperature measurements at a depth of $100 \mathrm{~m}$. The root mean square error between the two data sets is $1.6{ }^{\circ} \mathrm{C}$. The most likely cause of discrepancies between the two data sets is upwelling of warmer water from depth (e.g. Brassington, 2007; Shepley, 2007). However, the effect of urban areas may also be significant locally (Banks et al., 2009b, Headon et al., 2009). The data reflect the two major influences of location and elevation on air temperature. The range in values is $4-17^{\circ} \mathrm{C}$ with the lowest values corresponding with the highest topography. Variation occurs between regions; the SW and eastern England are warmer and there are 
localised higher values across the Central Belt of Scotland. There is also however considerable variation within regions. For instance, within the SW of England temperatures at $100 \mathrm{~m}$ depth vary between $10^{\circ} \mathrm{C}$ and $17^{\circ} \mathrm{C}$.

\section{Groundwater}

Groundwater conditions can affect the efficiency of a closed loop system, particularly as the thermal properties of unconsolidated sediments and rock are dependent upon the level of saturation. Low permeability rocks such as mudstones are generally saturated within a few metres of the ground surface, irrespective of elevation. In more permeable sandstones and limestones, the unsaturated zone thickness can be large, particularly at high elevations, and may alter seasonally. Sandstones, unless Palaeozoic or older in age, tend to have both primary intergranular and secondary fracture permeability and hence seasonal water level fluctuations are generally less than those observed in limestones where the predominant mechanism of groundwater flow is via secondary fractures. Therefore, in the UK, the main areas where closed loop collector systems will be less efficient are beneath areas of higher ground underlain by limestone (e.g. the Lincolnshire Wolds and the Cotswolds). The Chalk is an exception to this, as due to its very small pore throat size (median $0.7 \mu \mathrm{m}$ or less; Allen $\mathrm{el}$ al., 1997), the water content of the unsaturated zone is nearly as high as that of the saturated zone and hence the thermal conductivities of both will be similar. Hence, even where the water level is deep, the Chalk may be suitable for closed loop collector systems. Figure 5 shows that for most of Great Britain the unsaturated zone is likely to be effectively less than 10 m thick.

In confined aquifers the water level may rise above the depth at which water is first struck, and, if overflowing artesian conditions are encountered, this can complicate the construction and completion of the borehole. Other potential issues include drilling on contaminated sites that can result in the pollution of aquifers by the migration of surface contaminants down 
poorly constructed boreholes or piles (Westcott et al., 2003) and the connection of separate aquifer horizons which can be prevented by casing through the upper aquifer or a securely grouted section in the intervening aquitard. The requirement for grouting also has the advantage of providing a good thermal contact above the water table provided that a suitable, high thermal conductivity grout is used. Unless a biodegradable or low toxicity fluid is used within the collector loops, the hydrogeology and direction of groundwater flow need to be considered in closed loop systems, particularly in horizontal slinky systems (which are more prone to accidental damage) or in aquifers used for potable supplies.

Poor quality groundwater can also be an issue, as high total dissolved solids contents, particularly high chloride and sulphate ion concentrations, can be corrosive to some casing materials. The oxidation of sulphide minerals by exposure to air, in underground mines or surface spoil heaps, produces acidic, dissolved metals and sulphate. Acid mine drainage is a major source of pollution in many mining areas, however as the sulphide oxidation reaction is exothermic, Banks et al. (2004) have speculated that this geochemical energy could be used by heat pumps.

Where the collector loop is below the water table in an aquifer with significant groundwater flow, heat transport away from the site will occur. This can be helpful for single borehole cooling or heating systems in dispersing warmth or coolth, respectively, away from the borehole and bringing new cooler or warmer groundwater towards the borehole. However, where several boreholes are drilled for a larger cooling or heating system, or separate schemes are in close proximity, thermal interference can occur causing problems.

Groundwater flow can have a significant impact on the GSHP design. The complexity of both the GSHP design and the heat flow equations means that analytical solutions are not suitable and numerical modelling may be required. However, an indication of whether groundwater flow might be significant can be gained by comparing the relative impact on the heat 
transport caused by conduction and that caused by convection (also referred to as forced convection or advection). This comparison can be used to decide whether further numerical modelling is required. The parameter that is used for this comparison is the Peclet number for energy transport, which is a dimensionless variable obtained from consideration of the convection-conduction equation, i.e.

$$
P_{e}=\frac{\rho_{w} c_{w} q L}{\kappa_{e f f}}
$$

where $P_{e}=$ Peclet number, $\rho_{w}=$ density of water $\left(\mathrm{kg} \mathrm{m}^{-3}\right), c_{w}=$ specific heat of water, $\left(\mathrm{J} \mathrm{kg}^{-1}\right.$ $\left.\mathrm{K}^{-1}\right), q=$ water specific discharge $\left(\mathrm{m} \mathrm{s}^{-1}\right), L=$ length scale $(\mathrm{m}), k_{\text {eff }}=$ thermal conductivity of aquifer $\left(\mathrm{W} \mathrm{m}^{-1} \mathrm{~K}^{-1}\right)$, [Note: $q=$ hydraulic conductivity $\mathrm{x}$ hydraulic gradient].

Large Peclet numbers mean that convective transport is dominant whilst small numbers imply that conductive transport is dominant. In principle this convection becomes important when the Peclet number exceeds 1 , but this is slightly dependent on the choice of the characteristic length (Bear, 1972). This length scale is an indication of both the borehole spacing and depth (thickness of saturated aquifer penetrated). Table 3 indicates the Peclet number for a variety of materials and groundwater flow velocities.

Open loop systems can provide more energy than closed loop systems for the same depth of borehole, but can only be constructed where it is possible to abstract significant amounts of groundwater from an aquifer as, although systems are generally non-consumptive overall (due to reinjection), they require the availability of a water resource in the first place. Hydrogeological (or aquifer) maps are available for the UK indicating areas where there may be potential for significant abstractions. In addition to the above considerations for closed loop systems, the following also need to be taken into account. 
The aquifer properties of the rock (porosity, permeability, hydraulic conductivity, transmissivity and storage coefficient) will affect both the availability of the required yield and also the interference (both hydraulic and thermal) of any multi-borehole system. For UK aquifers, the aquifer properties manuals (Allen et al, 1997, Jones et al, 2000, Graham et al, 2006) are useful sources of these data. When several boreholes are constructed to obtain the required yield, it is possible that interference effects (between the zones of drawdown) could have a significant impact on yield. Interference effects can be minimised by the careful siting of the boreholes but this requires a detailed knowledge of the hydrogeology of the site. Licences are required for both abstraction and the discharge (or reinjection) of the hotter or cooler water.

Generally, large scale systems are designed for cooling or for aquifer thermal energy storage and there is a requirement to reinject large volumes of groundwater back into the aquifer. This is more difficult if the aquifer is artesian. The hydraulic gradient induced by abstraction (drawdown) and reinjection (hydraulic mound) from two relatively closely spaced boreholes is likely to greatly exceed the natural hydraulic gradient. If the system is used solely for cooling, thermal interference is likely to eventually become a problem and, in aquifer thermal energy storage schemes, it is important they are designed with balanced thermal loads over each annual operating cycle. It is possible that the injection borehole will not accept water at the same rate that it was abstracted, due to air entrainment and/or borehole clogging by particulate matter or growth of biofilms. Altering the temperature of the water will alter the solubility of some minerals and hence the water chemistry.

Water quality, as well as possibly being corrosive to any casing, is of importance in open loop systems, particularly if the water is pumped through the heat exchanger. If ions such as iron and manganese precipitate due to oxidation, they can cause clogging. It is therefore important to keep reducing groundwaters in a closed system, preventing them coming into 
contact with the oxygen in the atmosphere. Calcite may precipitate due to differences in carbon dioxide concentration and/or temperature and cause scaling and hydrogen sulphide may accumulate. Therefore groundwaters containing dissolved gases need to be kept at a high pressure to prevent degassing. If the water quality is particularly poor, a 'prophylactic' heat exchanger, often with a storage tank to buffer variations in flow, can be installed (Banks, 2008).

However, not all the heat added to the water from cooling systems will be dissipated via natural or induced groundwater flow. A large proportion of the heat will be absorbed and stored in the rocks themselves and may provide a useable source of heat. The converse applies if the system is used for heating purposes.

\section{Ground conditions and geotechnical properties}

When a GSHP system is installed there are a number of preliminary ground engineering aspects that need to be considered, in particular: the thickness and the nature of any superficial deposits; the depth of any weathered bedrock geology; the strength of the bedrock geology and any hazardous ground conditions. It is vital that these aspects are assessed to ensure that the appropriate GSHP installation is designed, the correct method of installation is used (drilling or trenching) and hence the installation is appropriately costed. In the UK the superficial and bedrock geology are very variable and form some of the most complex geological terrains in the world. There are a number of datasets, now in digital form, that are of particular interest at the preliminary desk study phase for a GSHP installation. These are briefly discussed below.

DigMapGB is a digital geological data set that covers all of Great Britain's bedrock (formerly known as solid), superficial (formerly known as Quaternary), artificial (man-made e.g. embankments, road cuttings) and mass movement (e.g. landslides and foundered strata) 
deposits. These data sets allow the geological conditions encountered at a site to be identified and hence the ground conditions for a ground source heat pump installation to be predicted. The characteristics (lithology) of the bedrock, superficial, artificial and mass movement deposits are derived from the British Geological Survey’s mapped 1:50,000 scale data.

The superficial thickness map for Great Britain has been created by assessing and modelling over one million borehole records held in the BGS archives. The model has been derived from geological rockhead information and provides an estimated thickness of superficial material and therefore a depth to bedrock units. The modelling uses geological map and digital terrain data to assist in the interpolation of the borehole dataset and the data provides thickness estimates on a $50 \mathrm{~m}$ by $50 \mathrm{~m}$ grid basis (see Figure 6 ).

The Superficial and Bedrock Engineering Strength and Relative Density dataset has been created using a classification that has applied the geotechnical parameter ranges for strength and density as described by BS5930:1999: Code of practice for site investigations (British Standards Institution, 1999); see Table 4 and 5. This classification has then been applied to all deposits in the BGS DigMapGB Superficial and Bedrock (1:50, 000 scale) geological data sets. Each deposit has been given a range of either strength or relative density values depending on whether the material is consolidated or granular in nature. This has then enabled a minimum and maximum strength and combined density map of Great Britain to be produced (Figures $7 \mathrm{a}$ and $\mathrm{b}$ ). A combination of geotechnical data cited in the literature and, where possible, site specific drilling data extracted from site investigation borehole records held in the BGS National Geoscience Data Centre (NGDC) and National Geotechnical Database has been used to aid in the classification of the dataset.

\section{Conclusions}


The preceding sections have discussed some of the geological factors that influence the performance and hence design of a GSHP system and this has been illustrated with some UK data. The geology of the UK is complex and varied and so it is not possible to have general design rules for the ground collector loops of closed loop systems or for the collector wells for open loop systems. For any individual system design, site specific information is required. For high capacity GSHP systems it is likely that some site investigation will be necessary. This is likely to include a thermal response test that provides the most accurate estimate of the thermal properties at a site (Banks, 2008). However, such investigations are expensive and are unlikely to be undertaken for individual domestic properties. For these cases the data sets described in this paper should be of use in designing the system. It is possible to obtain customised reports from the British Geological Survey on a site specific basis, but this does incur a fee. Alternatively individual GSHP installers may be able to apply their own experience in order to create the optimum design.

The effective use of site specific geological information will lead to improved GSHP design that will in turn encourage the take-up of GSHPs.

\section{Acknowledgements}

This paper is published by permission of the Executive Director of the British Geological Survey (NERC).

\section{References}

Allen, D J, Brewerton, L J, Coleby, L M, Gibbs, B R, Lewis, M A, MacDonald, A M, Wagstaff, S J And Williams, A T. 1997. The physical properties of major aquifers in England and Wales. British Geological Survey Technical Report WD/97/34, Environment Agency R\&D Publication 8. British Geological Survey. 
Banks, D., Skarphagen, H., Wiltshire, R. And Jessop, C., 2004, Heat pumps as a tool for energy recovery from mining wastes. In: Gieré, R. and Stille, P. (eds.), Energy, Waste and Environment: a Geochemical Perspective, Geological Society Special Publication 236: 499-513.

BANKS, D. 2008. An introduction to Thermogeology: ground source heating and cooling. Blackwell Publishing Ltd, Oxford, UK, 339p.

BANKS, D. 2009. An introduction to thermogeology and the exploitation of ground source heat. Quarterly Journal for Engineering Geology and Hydrogeology, this volume.

Banks, D. Fraga Pumar, A. And Watson I. 2009a. The operation of Scottish MiewaterBased Ground Source Heat Pump Systems. Quarterly Journal for Engineering Geology and Hydrogeology, this volume.

Banks, D., Gandy, C.J., Younger, P.L., Withers, J. And Underwood, C. 2009b. Anthropogenic thermogeological "anomaly" in Gateshead, Tyne and Wear, UK. Quarterly Journal of Engineering Geology and Hydrogeology, this volume.

Barker, J A, Downing, R A, Gray, D A, Findlay, J, Kellaway, G A, Parker, R H and RolLIN, K E. 2000. Hydrogeothermal studies in the United Kingdom. Quarterly Journal of Engineering Geology and Hydrogeology, 33, 41-58.

BEAR, J. 1972. Dynamics of Fluids in Porous Media. American Elsevier, New York.

DBERR (Department for Business Enterprise \& Regulatory Reform). 2007. Update on heat pumps - ground source heat pumps: updated 30 Nov 2007.

BloOmer, J R. 1981. Thermal conductivities of mudrocks in the United Kingdom. Quarterly Journal of Engineering Geology, London, 14, 357-362.

BRASSINGTON, F C. 2007. A proposed conceptual model for the genesis of the Derbyshire thermal springs. Quarterly Journal of Engineering Geology and Hydrogeology, 40, $35-46$. 
British StANDARds InStITUTION. 1999. Code of practice for site investigations. BS 5930. (London: British Standards Institution.)

CURTIS, R. 2001. Earth energy in the UK. Geo-Heat Center Bulletin, 22, No. 4, 23-30.

Curtis, R, Lund, J, SANNer, B, RyBach, L And Hellström G. 2005. Ground source heat pumps - geothermal energy for anyone, anywhere: Current worldwide activity. Proceedings World Geothermal Congress 2005, Antalya, Turkey, 24-29 April 2005, 1-9.

DOWNING, R A AND GRAY, D A. 1986. Geothermal resources of the United Kingdom. Journal of the Geological Society, London, 143, 499-507.

EEBPP (Energy Efficiency Best Practice Programme). 2000. Heat pumps in the UK - a monitoring report. General Information Report 72.

FRY, V. 2009. Lessons from London: Regulation of open loop ground source heat systems in London. Quarterly Journal For Engineering Geology And Hydrogeology, This volume.

Gale, I. 2004. GSHP Site Characterisation. Carbon Trust research, development and demonstation projects, 2002-08-026-4-3, Final project report.

Graham, M T, Ball, D F, O Dochartaigh, B E, Irving, K and Simpson, E, 2006. Scottish aquifer properties, 2006 interim report. Report CR/06/073N, British Geological Survey.

HEADON, J. BANKS, D, WATERS A AND ROBINSON V. 2009. Regional Distribution of Ground Temperature in the Chalk Aquifer of London. Quarterly Journal for Engineering Geology and Hydrogeology, this volume. 
HEEBPP (Housing Energy Efficiency Best Practice Programme). 2003. Domestic Ground Source Heat Pumps: Design and installation of closed-loop systems. Good Practice Guide 339.

Jones, H K, Morris, B L, Cheney, C S, Brewerton, L J, Merrin, P D, Lewis, M A, MacDonald, A M, Coleby, L M, Talbot, J C, McKenzie, A A, Bird, M J, Cunningham, J And Robinson, V K. 2000. The physical properties of minor aquifers in England and Wales. British Geological Survey Technical Report WD/00/04, Environment Agency R\&D Publication 68, British Geological Survey.

KeERy, J S, Binley, A., Crook, N. AND SMith, J W N. 2007. Temporal and spatial variability of groundwater - surface water fluxes: Development and application of an analytical method using temperature time series. Journal of Hydrology, 336, 1-16

Lee, M K, Brown, G C, Webb, P C, Wheildon, J And Rollin, K E. 1987. Heat flow, heat production and thermo-tectonic setting in mainland UK. Journal of the Geological Society, London, 144, 35-42.

LiNACRE, E AND GEERTS, B.1997. Climates and weather explained. Routledge, London, UK, $432 \mathrm{pp}$.

OndrekA, J, RÜsgen M I, Stober, I, AND CZurdA, K. 2007. GIS-supported mapping of shallow geothermal potential of representative areas in south-westernGermanyPossibilities and limitations. Renewable Energy, 32, 2186-2200.

PERRY, M AND Hollis, D. 2005a. Development of a new set of long-term averages for the UK. International Journal of Climatology, 25, 1023-1039.

PerRy, M AND Hollis, D. 2005b. The generation of monthly gridded datasets for a range of climatic variables over the United Kingdom. International Journal of Climatology, 25, 1041-1054. 
RAFFERTY, K. 2001. A guide to on-line geological information and publications for use in GSHP site characterization. Geo-Heat Center Bulletin, 22, No. 1, 31-37.

RoBERTSON, E C. 1988. Thermal properties of rocks. Open-file report 88-441, United States Geological Survey.

Rollin, K E. 1987. Catalogue of geothermal data for the land area of the United Kingdom. Third revision: April 1987. Investigation of the Geothermal Potential of the UK, British Geological Survey.

Rollin, K E. 1995. A simple heat-flow quality function and appraisal of heat-flow measurements and heat-flow estimates from the UK Geothermal Catalogue. Tectonophysics, 244, 185-196.

ROLLIN, K E. 2002. Assessment of BGS data for ground source heat pump installations in the UK. Internal Report IR/02/196, British Geological Survey.

Rybach, L AND SANNER, B. 2000. Ground-source heat pump systems; the European experience. Geo-Heat Center Bulletin, 21, No. 1, 16-26.

SAnNer, B, Karytsas, C, Mendrinos, D And Rybach, L. 2003. Current status of ground source heat pumps and underground thermal energy storage in Europe. Geothermics, 32, 579-588.

SHEPLEY, M G. 2007. Analysis of flows from a large Carboniferous Limestone drainage adit, Derbyshire, England. Quarterly Journal of Engineering Geology and Hydrogeology, 40, 123-135.

Westcott, F. J., Smith, J.W.N. And Lean, C.M.B. 2003. Piling in contaminated ground: environmental impacts, regulatory concerns and effective solutions. Engineering Geology, 70, 259-268. 


\section{Table 1}

\begin{tabular}{|l|c|c|}
\hline \multicolumn{1}{|c|}{ Class } & $\begin{array}{c}\text { Thermal Conductivity } \\
\mathrm{W} \mathrm{m}^{-1} \mathrm{~K}^{-1}\end{array}$ & $\begin{array}{c}\text { Thermal diffusivity } \\
10^{-6} \mathrm{~m}^{2} \mathrm{~s}^{-1}\end{array}$ \\
\hline Sand (gravel) & 0.77 & 0.45 \\
\hline Silt & 1.67 & 0.60 \\
\hline Clay & 1.11 & 0.54 \\
\hline Loam & 0.91 & 0.49 \\
\hline Saturated sand & 2.50 & 0.93 \\
\hline Saturated silt or clay & 1.67 & 0.66 \\
\hline
\end{tabular}

Table 1. Typical thermal properties for superficial deposits (Gale, 2004).

\section{Table 2}

\begin{tabular}{|l|c|c|}
\hline \multicolumn{1}{|c|}{ Rock } & $\begin{array}{c}\text { Thermal conductivity } \\
\mathrm{W} \mathrm{m}^{-1} \mathrm{~K}^{-1}\end{array}$ & $\begin{array}{c}\text { Thermal diffusivity } \\
10^{-6} \mathrm{~m}^{2} \mathrm{~s}^{-1}\end{array}$ \\
\hline Basalt & 1.80 & 0.685 \\
\hline Dunite & 4.56 & 0.947 \\
\hline Granite & 3.30 & 1.000 \\
\hline Granodiorite & 3.18 & 0.719 \\
\hline Gneiss & 3.01 & 1.224 \\
\hline Quartzite & 5.03 & 2.952 \\
\hline Salt & 4.87 & 3.060 \\
\hline Anhydrite & 5.40 & 2.242 \\
\hline Clay & 1.50 & 0.950 \\
\hline Clay marl & 2.13 & 0.934 \\
\hline Limestone & 2.73 & 1.054 \\
\hline Marl & 2.69 & 1.118 \\
\hline Marly clay & 2.30 & 0.894 \\
\hline Sandstone & 2.80 & 1.645 \\
\hline
\end{tabular}

Table 2. Representative values of thermal diffusivity and thermal conductivity for various rock types (Rollin, 2002). 
Table 3

\begin{tabular}{|c|c|c|c|c|}
\hline $\begin{array}{l}\text { Geology } \\
\text { (Saturated) }\end{array}$ & $\begin{array}{l}\text { Typical Hydraulic } \\
\text { gradient }\left(\mathrm{m} \mathrm{km}^{-1}\right) \text { and } \\
\text { as a [ratio] }\end{array}$ & $\begin{array}{l}\text { Hydraulic } \\
\text { conductivity, } \\
\left(\mathrm{m} \mathrm{d}^{-1}\right)\end{array}$ & $\begin{array}{l}\text { Thermal } \\
\text { conductivity (W } \\
\left.\mathrm{m}^{-1} \mathrm{~K}^{-1}\right)\end{array}$ & $\begin{array}{l}\text { Peclet } \\
\text { number }\end{array}$ \\
\hline Chalk dipslope & $\begin{array}{ll}1 & {[0.001]}\end{array}$ & 10 & 1.8 & 2.7 \\
\hline Sherwood Sst. (unconfined.) & $2 \quad[0.002]$ & 5 & 3.4 & 1.4 \\
\hline Lincs. Lst. (unconfined) & $\begin{array}{ll}1 & {[0.001]}\end{array}$ & 10 & 2.2 & 2.2 \\
\hline Jurassic Clay & $10 \quad[0.010]$ & 0.001 & 1.5 & $3.2 \times 10^{-3}$ \\
\hline Tertiary sands and clay & $\begin{array}{ll}5 & {[0.005]}\end{array}$ & 4.0 & 1.9 & 5.1 \\
\hline Metamorphic upland & $\begin{array}{ll}5 & {[0.005]}\end{array}$ & 0.001 & 3.2 & $7.6 \times 10^{-4}$ \\
\hline Igneous upland & $10 \quad[0.010]$ & 0.001 & 3.1 & $1.6 \times 10^{-3}$ \\
\hline
\end{tabular}

Table 3. Typical values of hydraulic gradient, hydraulic conductivity and thermal conductivity for British aquifers and the resultant Peclet number (bold where convective flow of groundwater can be expected to impact on the design of GSHP schemes).

Table 4

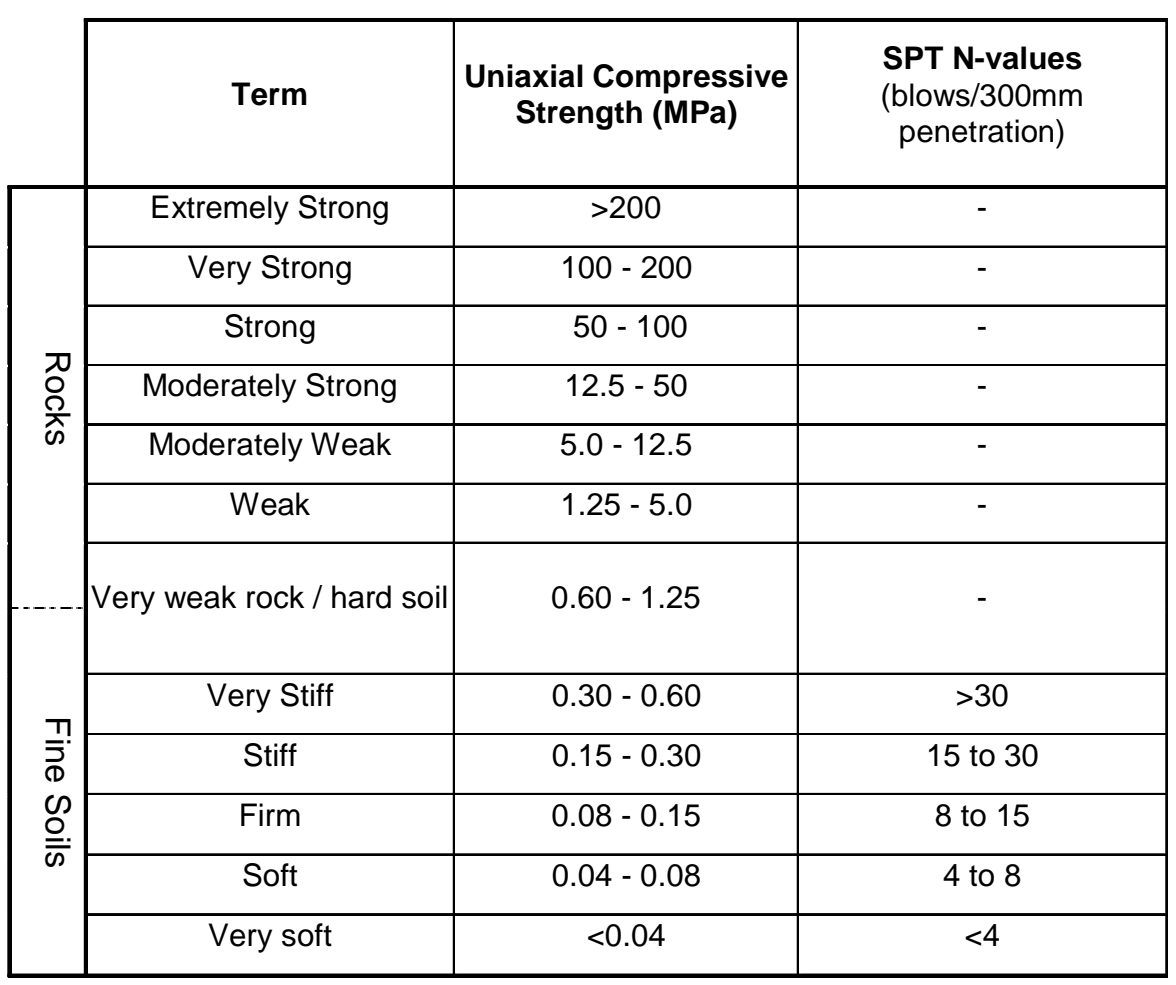

Table 4. Engineering strength classification for superficial and bedrock geology. The Standard Penetration Test (SPT) for granular soils is determined from the number of blows (N) from a $45 \mathrm{Kg}$ hammer required to drive a rod $300 \mathrm{~mm}$ into the ground. 
Table 5

\begin{tabular}{|c|c|c|c|c|}
\hline & TERM & $\begin{array}{c}\text { SPT N-values } \\
\text { (blows/300mm } \\
\text { penetration) }\end{array}$ & Density Code & $\begin{array}{c}\text { FIELD ASSESSMENT } \\
\text { (very approximate) }\end{array}$ \\
\hline \multirow{5}{*}{ 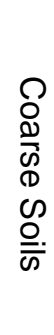 } & Very dense & $>50$ & VDEN & \multirow{3}{*}{$\begin{array}{c}\text { Requires pick for } \\
\text { excavation. } 50 \mathrm{~mm} \\
\text { wooden peg hard to } \\
\text { drive. }\end{array}$} \\
\hline & Dense & 30 to 50 & DENS & \\
\hline & Medium dense & 10 to 30 & MDEN & \\
\hline & Loose & 4 to 10 & LOOS & \multirow{2}{*}{$\begin{array}{c}\text { Can be excavated } \\
\text { with spade. } 50 \mathrm{~mm} \\
\text { wooden peg easily } \\
\text { driven. }\end{array}$} \\
\hline & Very loose & $<4$ & VLOO & \\
\hline \multirow{2}{*}{ 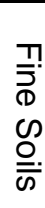 } & Compact & I & COMP & $\begin{array}{l}\text { Easily moulded or } \\
\text { crushed in fingers }\end{array}$ \\
\hline & Uncompact & I & UNCO & $\begin{array}{c}\text { Can be moulded or } \\
\text { crushed by strong } \\
\text { pressure in the fingers }\end{array}$ \\
\hline
\end{tabular}

Table 5. Density classification for unconsolidated material. 


\section{Figure captions}

Figure 1. Sketch illustrating the main factors that impact on the design of the ground component of a GSHP system. Superficial deposits (drift cover) overlie dipping solid geology indicated by their thermal conductivities $\mathrm{k} 0-\mathrm{k} 4$. The depth extent of the weathered zone is indicated by the dotted line $\mathrm{WZ}$ and the water level by the dotted line WT. The solid line labelled temperature is an isotherm. HL and VL are horizontal and vertical collector loops respectively.

Figure 2. Seasonal variation of the near surface temperature profile. Note there is a progressive phase shift with depth of the temperature function.

Figure 3. Heat flow map of the UK. Note values are in milliWatts per metre squared.

Figure 4. Estimated temperatures for Great Britain at $100 \mathrm{~m}$ depth, based on estimated mean annual air temperatures and one dimensional, vertical, heat conduction.

Figure 5. Map showing depth to groundwater for Great Britain Chalk outcrop areas are shown as having water within $2.5 \mathrm{~m}$ of the ground surface, as the presence of porewater in the unsaturated zone means that its thermal properties are similar to those of the saturated zone.

Figure 6. Superficial Thickness map of Great Britain.

Figure $7 \mathrm{a}$ and $\mathrm{b}$. (a) Engineering strength and density maximum and (b) engineering strength and density minimum maps of Great Britain. For an explanation of the terms in the key see Tables 4 and 5. 


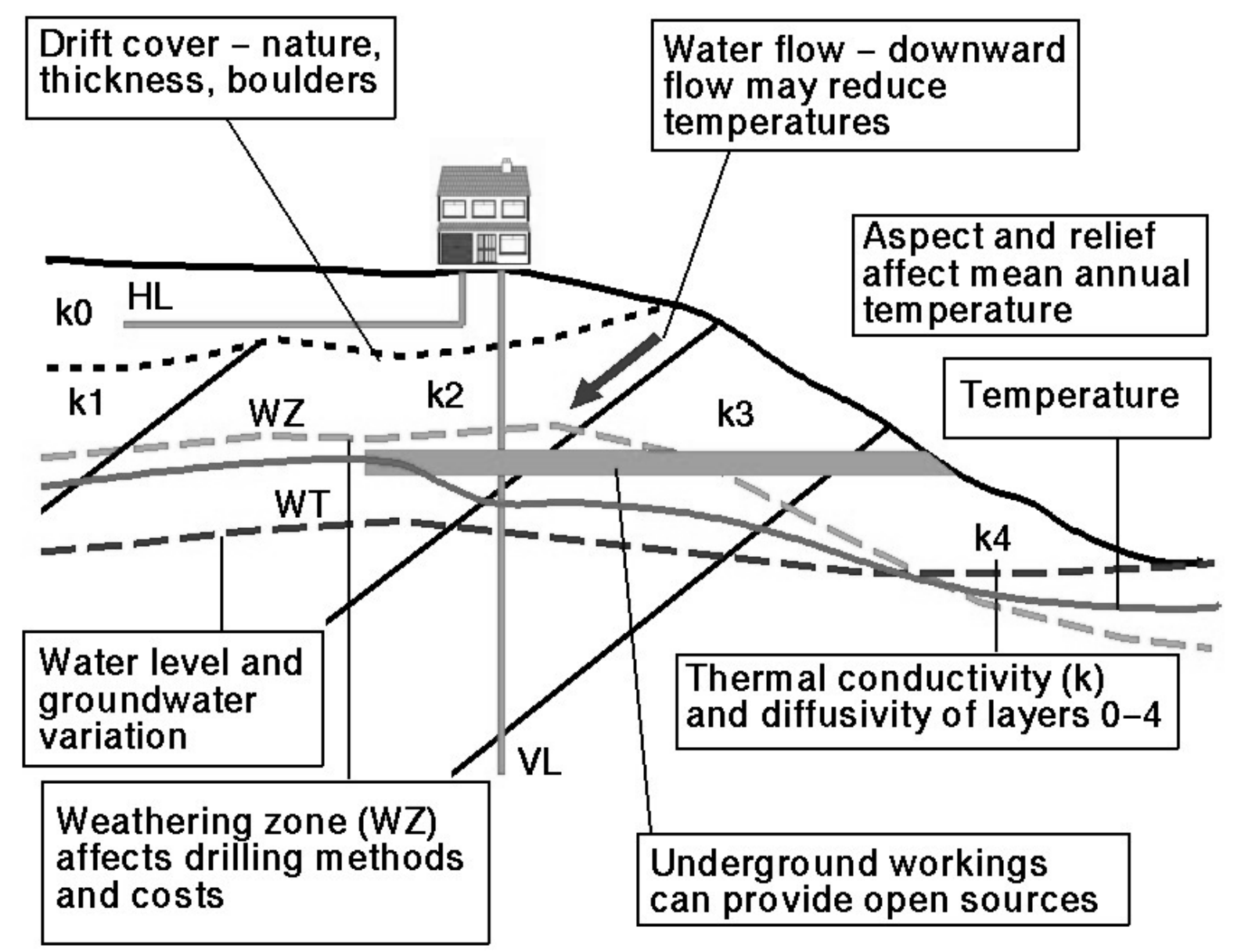

Figure 1 


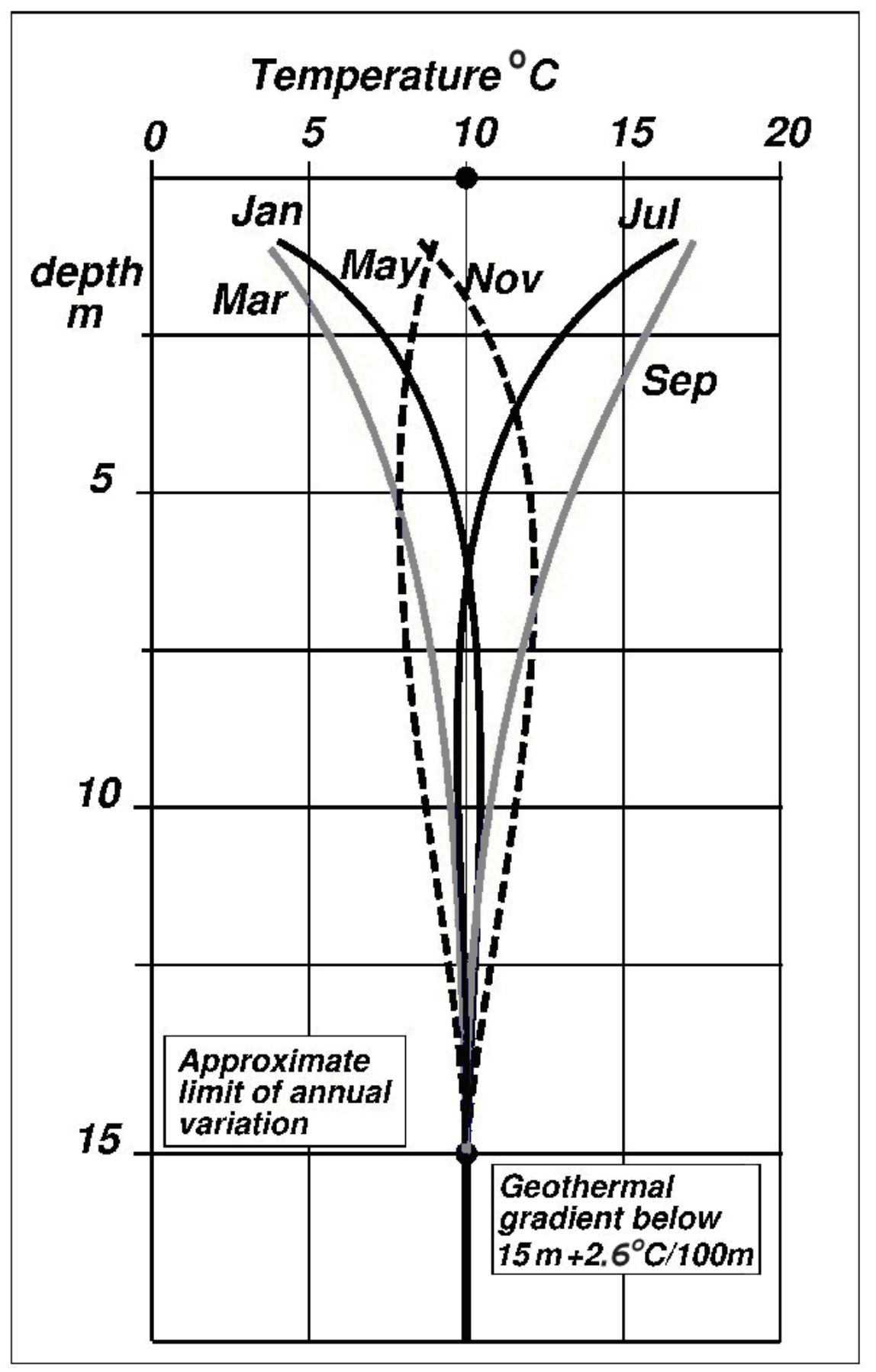

Figure 2 


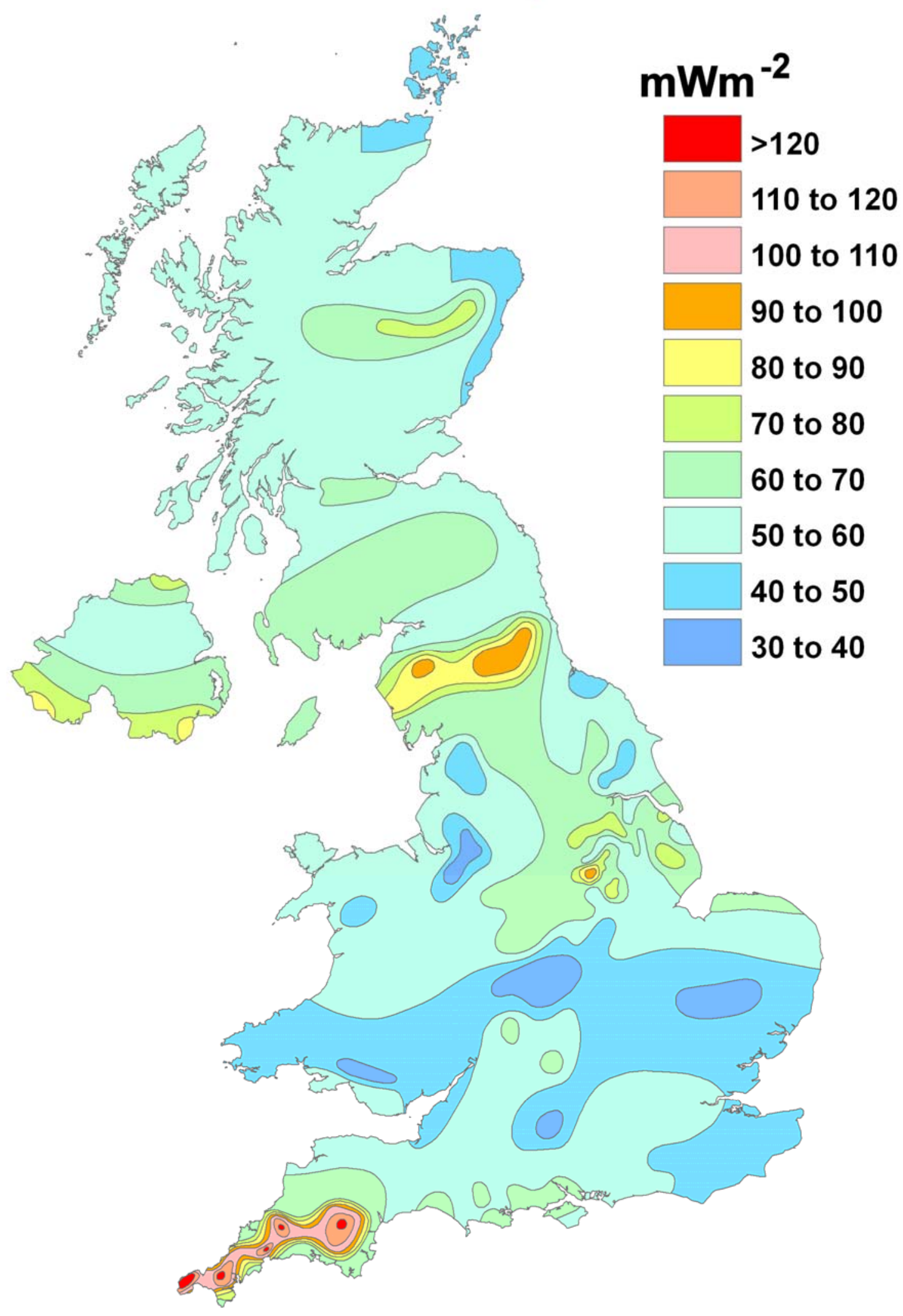

Figure 3 


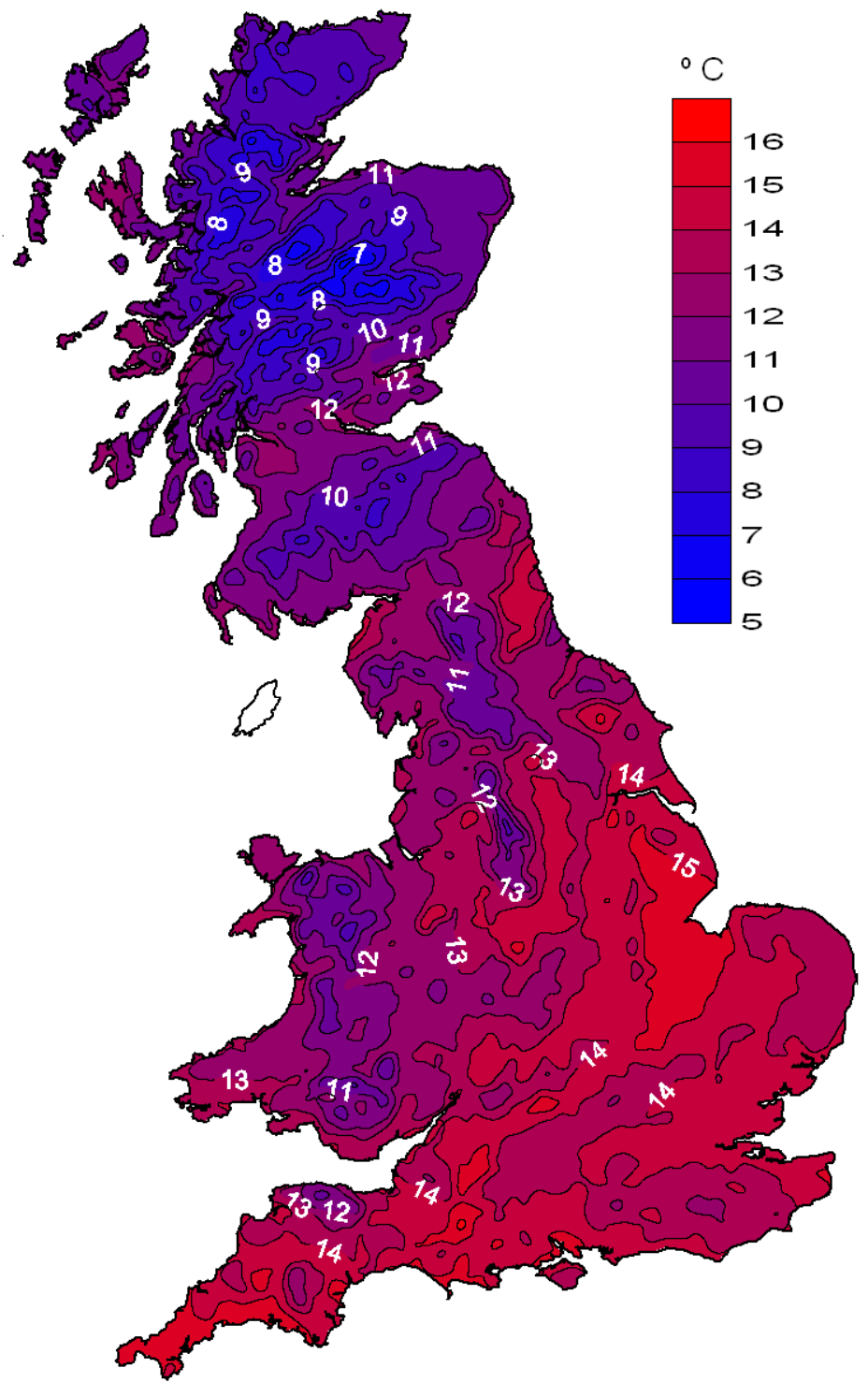

Figure 4 




Figure 5 


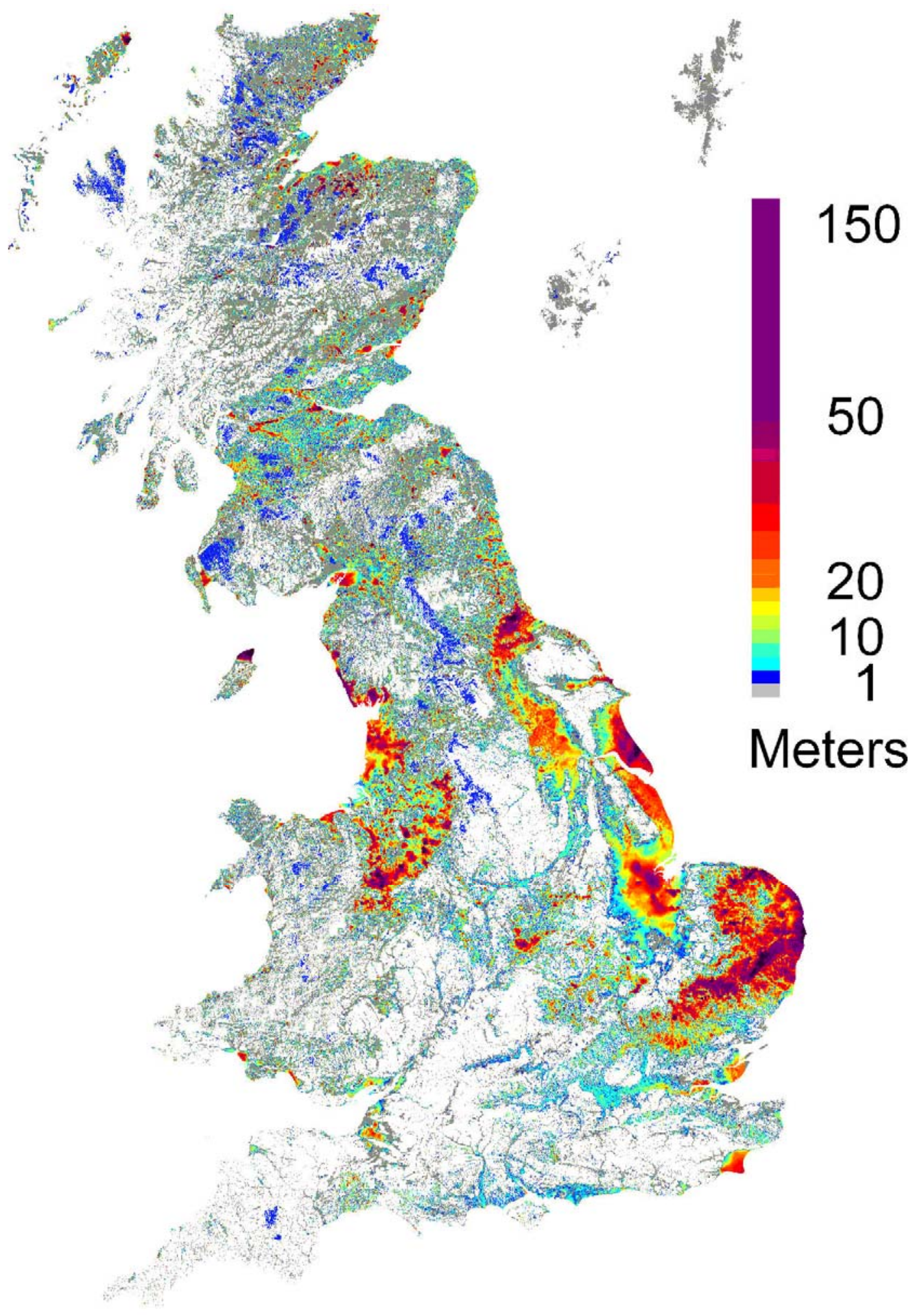

Figure 6 


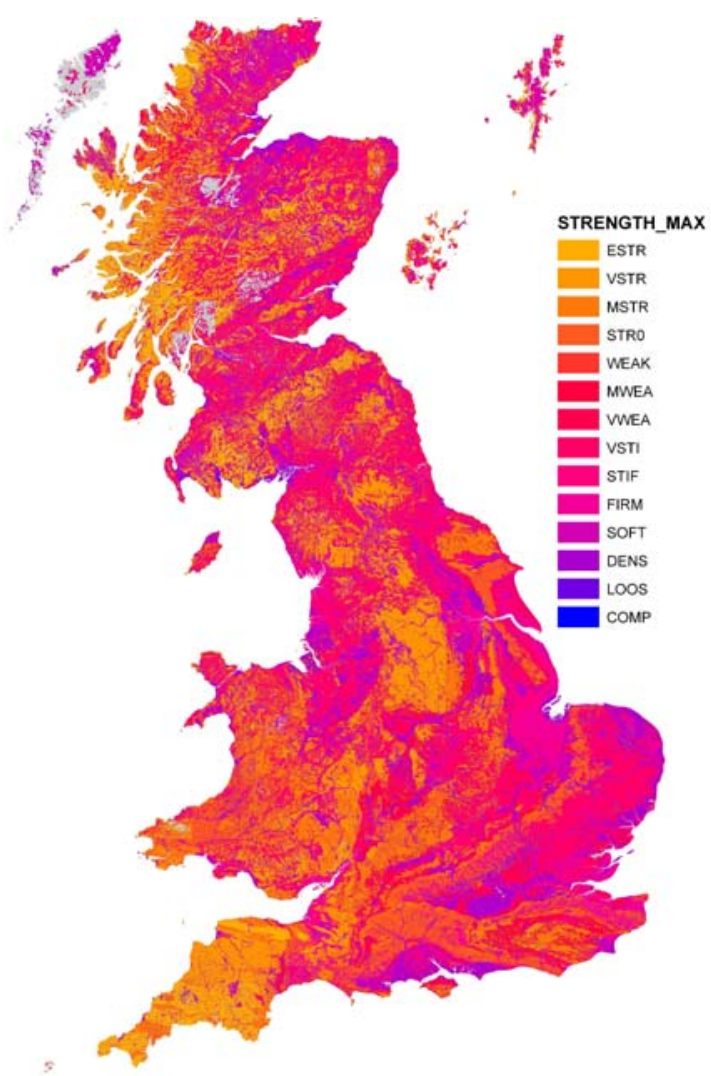

Figure $7 \mathrm{a}$

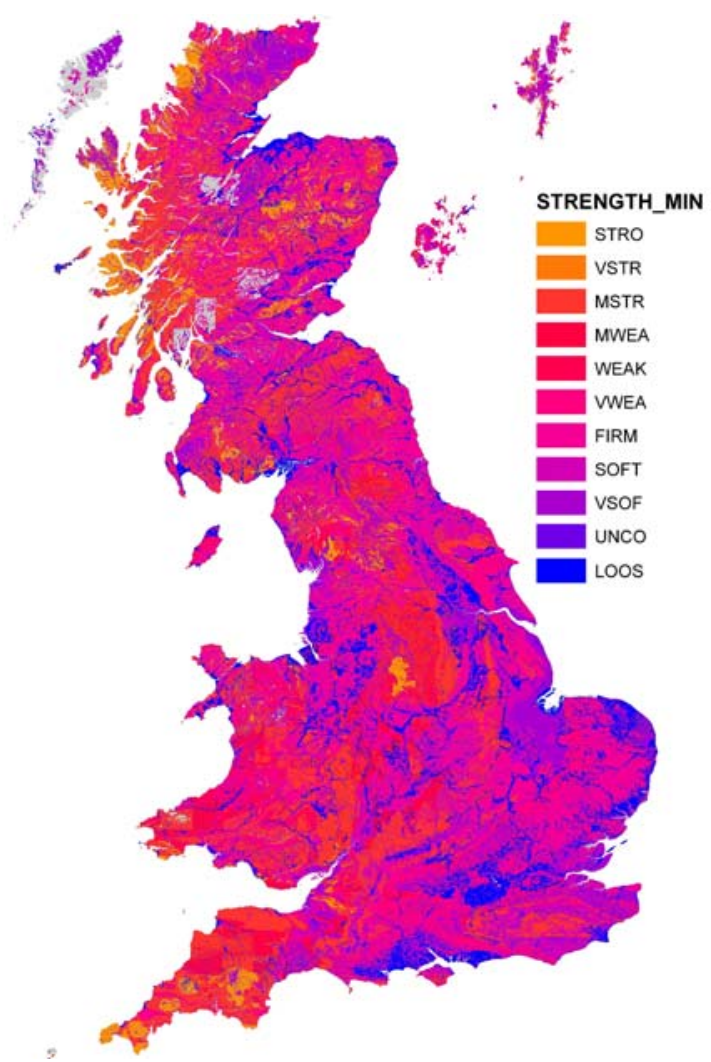

Figure $7 b$ 